\title{
Co nam dzisiaj po Jacques'u Rancierze?
}

Michał Krzykawski

TEKSTY DRUGIE 2018, NR 6, S. 146-153

DOI: $10.18318 /$ td.2018.6.11

$\mathbf{W}$ przedmowie do opublikowanej już ponad dwadzieścia lat temu La Mésentente Jacques Rancière pisał: „Niezgoda nie jest konfliktem pomiędzy tym, kto mówi białe a kimś innym, kto mówi czarne. Jest ona natomiast konfliktem pomiędzy tym, kto mówi białe a kimś innym, kto mówi białe, lecz przez białe zupełnie nie rozumie tego samego lub zupełnie nie rozumie, że ta pierwsza osoba ma na myśli to samo, gdy mówi o bieli"1. Pojęcie niezgody, jednego z fundamentów rozwijanej przez francuskiego filozofa teorii polityki, charakteryzuje jednak również postawę i styl myślenia samego Rancière'a, którego filozoficzny modus operandi mogłyby ilustrować wyrażenia takie, jak: w odróżnieniu od, odwrotnie niż, w przeciwieństwie do. Taki obraz Rancière'a próbuje nam w każdym razie przedstawić Jerzy Franczak, autor pierwszego w Polsce całościowego omówienia

1 J. Rancière La Mésentente. Politique et philosophie, Galilée, Paris 1995, s. 12. Jeśli nie zaznaczono inaczej, wszystkie tłumaczenia są mojego autorstwa.

\section{Michał}

Krzykawski - dr, adiunkt na Uniwersytecie Śląskim w Katowicach, filolog, tłumacz, autor dwóch monografii i kilkudziesięciu artykułów z zakresu współczesnej filozofii francuskiej. Ostatnio opublikował Inne i wspólne. Trzydzieści pięć lat francuskiej filozofii (2017). Obecnie pracuje nad książką Słowa larwalne. Zarys technokrytyki ekonomii politycznej w erze big data, która ukaże się w przyszłym roku. Kontakt: michal.krzykawski@us.edu.pl 
wielowątkowego, lecz spójnego i podporządkowanego kilku powracającym założeniom projektu francuskiego filozofa ${ }^{2}$.Zaznaczę od razu, że jest to próba zakończona powodzeniem - „mistrzowski sztych w pierwszej próbie”, można by rzec. $Z$ tym jednak zastrzeżeniem, że owa próba dotyczy filozofa, który zrywa z porządkiem estetycznym ancien régime'u i wybiera drogę „mistrza ignoranta", podążając tropem zapomnianego pedagoga Jean-Josephe'a Jacotota i plebejskiego filozofa Louisa-Gabriela Gauny'ego obsadzonych tutaj w roli duchowych przewodników.

Powodzenie tej pierwszej próby wynika w dużej mierze z obranej strategii komentarza. Z jednej strony Franczak proponuje opowieść o Rancierze, która osadza myśl tego ostatniego na współczesnej (głównie paryskiej) scenie intelektualnej i pozwala podążać za sposobem, w jaki niezdyscyplinowany bohater opowieści interweniuje w określonych kontekstach, burząc mury porządków, specjalności i przyzwyczajeń, a jednocześnie budując swoją pozycję na intelektualnej lewicy. Z drugiej zaś strony komentator, świadomy nieuchronnej schematyczności, która ze snuciem opowieści się wiąże, dystansuje się od ustanawiania sztucznych klasyfikacji i postępuje w zgodzie z praktyką Rancière'a: łączyć ze sobą to, co wydaje się od siebie odległe, oraz oddalać od siebie to, co wydaje się złączone. Innymi słowy, przemieszczać linie sporów, wdając się w spory. Każda dobra książka o Rancierze musi być bowiem również książką o innych: o tych, którym filozof jawnie się sprzeciwia (Althusser, Bourdieu), o tych, których reinterpretuje (Kant), o tych, z którymi wchodzi w mniejsze lub większe dyskusje (Lyotard, Foucault, Badiou), o tych, których jawnie lub aluzyjnie krytykuje (Debord, Sloterdijk, Stiegler, Bauman), wreszcie o tych, których twórczość komentuje (przede wszystkim Flaubert, ale również Brecht, Balzak, Nabokov, Proust, Woolf i wielu innych). Jedynie odtwarzając te spory, możemy dostrzec żywotny charakter myśli Rancière'a, bez względu na to, czy mowa o rozróżnieniu na policję i politykę, o polityczności literatury, czy o skandalu demokracji.

2 J. Franczak Błądzq̨ce słowa. Jacques Rancière i filozofia literatury, Wydawnictwo IBL PAN, Warszawa 2017. Dalej odwołania zaznaczam w tekście podając numer strony.

3 Nawiązanie do Cyda Pierre'a Corneilla, w którym Roderyk zwraca się do Gomesa „Tacy jak ja za pierwszy raz każą o sobie / Sądzić, mistrzowskie dając sztychy w pierwszej probie" (P. Corneille Cyd albo Roderyk, przeł. Jan Andrzej Morsztyn, wyd. A. Karpiński i A. Stepnowski, Instytut Badań Literackich, Warszawa 1999, s. 42). W oryg. Mes pareils à deux fois ne se font point connaître / Et pour leurs coups d'essai veulent des coups de maître. Wywodzące się z Cyda powiedzenie Pour un coup d'essai, c'est un coup de maître przeszło do codziennego języka i określa sytuację, w której podjęcie pierwszej próby okazało się pełnym sukcesem. 
W tej podwójnej strategii Franczak, w odróżnieniu od Rancière’a, nie jest jednak kontrowersyjny i poprzestaje na przybliżeniu sensu licznych kontrowersji będących udziałem tego, kto jest tutaj przedmiotem komentarza. Efektem takiego zabiegu jest przede wszystkim czytelność i precyzja wywodu. Franczak zbyt dobrze zna pisma Rancière'a (które aktywnie czyta w oryginale, co jest odczuwalne), aby po „błądzących słowach” samemu błądzić. Nie maskuje się za przesadnie rozbudowaną metaforyką, nie prześlizguje się po pojęciach, nie mnoży powierzchownych analogii i skojarzeń z innymi myślicielami. Oferuje nam natomiast gruntownie przemyślaną książkę, która jest swoistym wprowadzeniem do filozofii Rancière'a (niekoniecznie filozofii literatury, do czego jeszcze powrócę), a jednocześnie stanowi niezbędny suplement do dostępnych po polsku tekstów francuskiego filozofa, takich jak Nienawiść do demokracji, Na brzegach politycznego, czy Dzielenie zmysłowego, bo tak właśnie, jak słusznie dowodzi Franczak na marginesie swojej analizy (99), należałoby przetłumaczyć le partage du sensible, ten tytuł i koncept zarazem ${ }^{4}$ - i nie jest to chyba uwaga bez większego znaczenia dla myśli autora, który wiele stron poświęca pojęciu aisthesis. Warto bowiem dodać, że Rancière Franczaka to w dużej mierze Rancière nieprzetłumaczony, a przez to funkcjonujący na rodzimym gruncie w sposób raczej akcydentalny. Można by było sobie życzyć, aby omówienie w książce głównych tez La nuit des prolétaires, Le maître ignorant, czy Le philosophe et ses pauvres, by wymienić tylko kilka skomentowanych w Btadzacych stowach pozycji, wywołało przynajmniej nieco większy ruch na ubogim rynku tłumaczeń współczesnej myśli francuskiej w Polsce, gdyż na długofalową politykę wydawniczą w tym zakresie raczej nie ma co liczyć (bo kto miałby ją wdrażać i komu miałoby na tym zależeć?). Tymczasem jedynie taki ruch mógłby stworzyć podstawowe warunki do sensownej debaty, która pozwoliłaby zrozumieć realne, a nie zapośredniczone przez poststrukturalistyczną recepcję stawki francuskich kontrowersji: pokoleniowych i międzypokoleniowych. W tym aspekcie Btądzace słowa, które przedstawiają Rancière'a w relacji do innych myślicieli, oferują bardzo pożyteczną lekturę.

Nie streszczę tutaj poszczególnych części wywodu zawartego w pięciu rozdziałach książki. Wyodrębniłbym jednak dwa powracające w każdej z nich wątki, które odpowiadają zresztą dwóm stałym, rozwijanym pod różnymi postaciami motywom myśli Rancière'a. Kanwą pierwszego motywu jest refleksja nad relacją między udziałami (parts) i częściami (parties) w odniesieniu

4 Por. J. Rancière Dzielenie postrzegalnego. Estetyka i polityka, przeł. M. Kropiwnicki, J. Sowa, Ha!art, Kraków 2007. 
do przestrzeni zmystowego, a więc do tego, co da się postrzec, poczuć i pojąć. Każda nowa konfiguracja tej przestrzeni wyznacza moment polityczny. Z polityką - pisze Rancière - mamy do czynienia wtedy, gdy „naturalny porządek dominacji zostaje przerwany przez instytucję części pozbawionych udziału [une part des sans-part]”. „Pojęcie sans-part - precyzuje Franczak - nie odnosi się po prostu do zdominowanych i wykluczonych. O ile zdominowany istnieje wyłącznie wewnątrz relacji do dominującego, to ten, kogo tyczy się termin sans-part, podważa samą dominację i odrzuca przypisywany mu status" (127). Franczak tłumaczy jednak ten polityczno-estetyczny wymiar myśli Rancière'a, wychodząc od jego nieszablonowych analiz kanonicznych dzieł literackich, zwłaszcza XIX-wiecznych powieści francuskich z Pania Bovary na czele. W teorii Rancière'a wynalazek fikcji powieściowej, tożsamy z narodzinami literatury w nowoczesnym znaczeniu tego słowa i zrywający z porządkiem przedstawieniowym belles-lettres, wyznacza rewolucję estetyczną, która dokonała się w XIX wieku. Scena literacka jest tutaj jednak postrzegana jako scena polityczna par excellence. Dzieje się tak dlatego, że wkraczają na nią tematy i osoby, które w poprzednim porządku nie mogły na niej zaistnieć, a przez to mieć swojego udziału w estetycznym przeżywaniu świata. Literatura - wyjaśnia Rancière na przykładzie absolutnej równości prozy ulubionego przezeń Flauberta - wprowadza demokratyczną zmianę „całego porządku świata, całego systemu stosunków panujących pomiędzy sposobami bycia, sposobami postępowania i sposobami mówienia"6. Słowa są równe, pękają hierarchie między tematami uznawanymi za godne i nobliwe a tematami uznawanymi za podłe i nikczemne, to jest (zbyt) prozaiczne. Tworzone przez powieściopisarzy frazy stają się „niemymi kamieniami” lub każda może podnieść i odczytać po swojemu.

Drugim motywem powracającym w analizie Franczaka jest jednostkowy - i w tym sensie niekomunistyczny - wymiar doświadczenia estetyczno-politycznego, które ma jednakowoż wymiar kolektywny o tyle, o ile zawsze jest dzielone w obrębie jakiejś zbiorowości i może doprowadzić do konfiguracji relacji między tym, co widzialne, a tym, co da się wypowiedzieć. Na szczególną uwagę zasługują tutaj pasjonujące analizy działalności XIX-wiecznych robotników, które Rancière podejmuje w La nuit des prolétaires czy La parole ouvrière.

5 J. Rancière La Mésentente, s. 31.

6 J. Rancière Politique de la littérature, Galilée, Paris 2007, S. 17.

7 Tamże, s. 21. 
Filozofa nie interesuje w nich walka czy przynależność klasowa, a zwłaszcza wyidealizowana wizja proletariatu jako zbiorowego i dziwnie bezpodmiotowego podmiotu dziejów, który oto (za sprawą objaśniającemu świat teoretykowi - dopowiedziałby Rancière w swym jednostkowym akcie rewolty przeciw Althusserowi) nabywa świadomość klasową i postanawia działać na rzecz budowana komunizmu. W tym sensie postawa Rancière'a względem proletariuszy przypomina tezy głośnej książki André Gorza, który w 1980 roku mówi „żegnaj” Marksowskiej teorii proletariatu i rozpoczyna swą walkę o uwolnienie czasu i zniesienie pracy w warunkach (neoliberalnej transformacji) kapitalizmu ${ }^{8}$. Przede wszystkim jednak Rancière zadaje kłam stereotypowemu wyobrażeniu robotniczego działacza. Studiując archiwa i odszukując w nich robotnicze odezwy, broszury i prywatną korespondencję, Rancière skupia się na konkretnych ludziach, którzy angażowali się w walkę, czytali, marzyli i kształcili się, a tym samym przekraczali granice definiujące ich tożsamość. Oddajmy głos Franczakowi:

Jérôme-Pierre Gilland, ślusarz; Charles Pénnekère, szewc; Antonia Chollet, krawcowa... La Nuit des prolétaires zaludniają dziesiątki podobnych postaci, wydanych na pastwę nędzy, niepewności i upokorzenia, a mimo to sięgających po pióro, angażujących się w utopijne projekty naprawy społecznej, poszukujących w literaturze wizji innego świata. Choć w swoich tekstach często użalają się na biedę i niesprawiedliwość, na ogół zgodnie wskazują największe cierpienie związane z poczuciem skradzionego czasu, z odkryciem, że ich życie upływa na monotonnych czynnościach służących wyłącznie jego podtrzymywaniu. Celem ich zmagań nie jest prawo do lenistwa, lecz do uczestnictwa w świecie idei i piękna oraz do kształtowania wspólnego świata. (217-218)

Osobiście uważam analizy ruchu robotniczego w XIX-wiecznej Francji za najciekawsze w bogatej twórczości Rancière'a. Z jednej strony okazują się one bardzo przydatne w kontekście europejskich półperyferii, takich jak Polska, i w odniesieniu do walk robotniczych prowadzonych przez pierwszą "Solidarność", z której Jan Sowa usiłował uczynić fundament swojej alternatywnej opowieści na przyszłość ${ }^{9}$. Aż się prosi, aby te analizy skonfrontować

\footnotetext{
8 Zob. A. Gorz Adieux au prolétariat. Au-delà du socialisme, Galilée, Paris 1980.

9 Zob. J. Sowa Inna Rzeczpospolita jest możliwa! Widma przeszłości, wizje przyszłości, W.A.B, Warszawa 2015.
} 
chociażby z badaniami poświęconymi kontrpublicznościom Ewy Majewskiej $^{10}$.Z drugiej strony zaś francuska percepcja klasowości - nierezygnująca z dającego się uniwersalizować, a przy tym nietracącego nic ze swojej jednostkowości doświadczenia estetycznego - mogłaby stworzyć przeciwwagę dla badań nad klasą uprawianych przez Richarda Hoggarta i charakterystycznych dla nieodżałowanej szkoły z Birmingham, które bardziej dążą do kulturowego uznania samej klasy w nieredukowalnie klasowym społeczeństwie, niż wskazać możliwość przekroczenia klasowych uwarunkowań"1 . I to właśnie w odniesieniu do uwarunkowań, czy też habitusu, dobrze opisany przez Franczaka fundamentalny spór Rancière'a z Bourdieu nabiera większego sensu, a tym samym nakazuje nie traktować zarysowanej przeze mnie różnicy franko-brytyjskiej jako nieprzepuszczalnej, zwłaszcza że porównanie Bourdieu z Hoggartem mogłoby stać się tematem ciekawej pod wieloma względami - od socjologicznej analizy klasy po doświadczenie autobiograficzne i motywacje psychologiczne, których Bourdieu konsekwentnie się wypierał - rozprawy akademickiej $^{12}$. Ta kreślona tu naprędce perspektywa relacyjna wydaje się zresztą dogodną okazją do tego, aby zapytać o motywacje psychologiczne urodzonego w 1940 roku w Algierze Rancière'a, który - opowiadając się za dezidentyfikacją jako formą walki ze specyficznie pojmowaną policją wszelki determinizm ekonomiczny i historyczny odrzuca równie zdecydowanie co Bourdieu psychologię, podczas gdy jego oficjalna biografia odsyła nas od narodzin bezpośrednio do Louisa Althussera i słynnego Czytania Kapitału.

Wchodzę tutaj jednak na ścieżki, na które Błądzace słowa się nie zapuszczają. Wydaje mi się w każdym razie, że w wywodzie Franczaka ten jednostkowy wymiar doświadczenia estetycznego, odnalezionego przez Rancière'a w marzeniach i pragnieniach XIX-wiecznych robotników, jest kluczowy o tyle, o ile pozwala zrozumieć, że zwrot ku klasycznym dziełom literackim, który charakteryzuje późniejsze francuskiego filozofa, wpisuje się w tę samą trajektorię myśli. Nie ma żadnego zerwania pomiędzy emancypującymi się robotnikami,

10 Zob. E. Majewska Kontrpubliczności ludowe i feministyczne. Wczesna "Solidarność" i czarne protesty, Książka i Prasa, Warszawa 2018.

11 Zob. R. Hoggart Spojrzenie na kulturę robotniczą w Anglii, przeł. A. Andros, Państwowy Instytut Wydawniczy, Warszawa 1976 oraz Kultura i hegemonia. Antologia tekstów szkoły z Birmingham, wyb. i red. M. Wróblewski, Wydawnictwo UMK, Toruń 2012.

12 Zob. À plusieurs voix sur L'après Pierre Bourdieu (hommages et auto-analyse), "Mouvements" 2004/2005 no 35, s. 150-162. DOI: 10.3917/mouv.035.0150. URL: https://www.cairn.info/revue-mouvements-2004-5-page-150.htm. 
którzy tworzą idee, piszą wiersze, myślą i upodmiotowiają się, redefiniują wspólnotę poprzez własne doświadczenia zmysłowe a Emmą Bovary, która estetyzuje świat za pośrednictwem fikcji, usiłując tym samym zmienić jego konfigurację i wyrwać się z rąk obiegowej mądrości uosabianej przez Karola. Doświadczenie miłej bezczynności, którą zachwalał wędrowiec Rousseau, nie jest - wbrew boleśnie przeżywanym i społecznie szkodliwym stereotypom klasowym - niedostępne robotnikowi. Rancière odnajduje je chociażby w opisie niedzielnej wycieczki na wieś pozostawionym przez pewnego XIX-wiecznego czeladnika. „Nie są to zapiski proletariusza - komentuje Franczak - który odpoczywa w czasie wolnym, odzyskując siły przed kolejnym tygodniem pracy. To zbiór impresji, opowieść estety, który oddaje się rozrywkom zarezerwowanym dla dobrze urodzonych: kontemplacji kształtów i światłocieni, stawianiu pytań, rozważaniu filozoficznych hipotez" (20).

Błądzace stowa przykładnie ten konsekwentny tor lotu francuskiego filozofa odtwarzają. Można by się zatem zastanawiać, czy jest to książka o filozofii literatury Jacques'a Rancière'a, jak głosi jej podtytuł, czy też - a takie jest moje odczucie czytelnicze - o jego filozofii tout court, której istotnym aspektem są analizy poświęcone literaturze jako jednej z możliwych przestrzeni doświadczenia estetycznego. Odnoszę wrażenie, że kładący duży nacisk na adyscyplinarność Rancière'a Franczak to również, a może przede wszystkim ktoś, kto - definiując się na czwartej stronie okładki jako „prozaik, eseista, literaturoznawca" - ma świadomość, że pisze książkę filozoficzną, której profesjonalnej oceny dokonają (co zresztą już się stało, z bardzo pozytywnym skutkiem) literaturoznawcy.„Piszę po to, aby przełamać granice oddzielające specjalności - filozofię, sztukę, nauki społeczne itd. Piszę dla tych, którzy również starają się burzyć mury między specjalnościami i rodzajami kompetencji" - wyznaje Rancière, a Franczak owo wyznanie czyni mottem swojego "«sam na sam» z Rancière'em" (9 i 29). Doprawdy trudno rozstrzygnąć w tej sytuacji, czyje są to słowa.

Pozostaje na koniec zapytać: co nam dzisiaj po Rancierze? W jaki sposób mamy praktykować jego skandaliczną demokrację „my, spóźnieni przybysze $\mathrm{z}$ dwudziestego pierwszego wieku", by przywołać tego, u kogo Rancière diagnozuje melancholijną lewicowość (276) ${ }^{13}$ ? Franczak tych pytań wprost nie 
stawia, a czasami można odnieść wrażenie, że ich sprytnie unika, zadowalając się prezentacją stanowiska samego Rancière'a w licznych sporach z innymi. Nie zmienia to jednak faktu, że takie pytania po lekturze Btądzących słów się narzucają. W obliczu braku odpowiedzi pozwolę sobie prowokacyjnie zacytować Stieglera, zdradzając tym samym własne preferencje: „Jacques Rancière słusznie przypomniał, że «polityczność» jest zmysłowa, co oznacza, że kwestia polityczna jest od razu kwestią estetyczną. Lecz dziwnie zignorował fakt, iż w epoce przemysłowej pałowana przez marketing zmysłowość stała się stawką w prawdziwej wojnie, w której bronią są technologie, a której ofiarami są jednostkowości, tak indywidualne, jak i zbiorowe («kulturowe») - do tego stopnia, że przyczynia się to do rozwoju potężnej nędzy symbolicznej"14. Pytanie o to jak w erze kapitalizmu platform czytać Rancière'a, aby - parafrazując atak Nietzschego pod adresem Kanta i przesuwając się o wiek do przodu - nie pozostawał on, ze swoim feblikiem do XIX-wiecznej literatury, "całkiem dwudziestem stuleciem"15, pozostaje zatem otwarte. Ale bez książki Franczaka nie sposób byłoby tego pytania sensownie postawić.

\section{Abstract}

\section{Michał Krzykawski}

UNIVERSITY OF SILESIA IN KATOWICE

What Good is Jacques Rancière Today?

Jerzy Franczak Błądzące słowa: Jacques Rancière ifilozofia literatury [Erring Words: Jacques Rancière and Philosophy of Literature], Instytut Badań Literackich, Warsaw 2017.

\section{Keywords}

Jacques Rancière, proletariat, workers' movement, democracy, political theory, aesthetics, novel

14 B. Stiegler De la misère symbolique 1. L'époque hyperindustrielle, Flammarion, Paris 2013 (2004), S. $14-15$.

15 Zob. F. Nietzsche Wola mocy, przeł. K. Drzewiecki, S. Frycz, vis-à-vis etiuda, Kraków 2016, s. 36. 